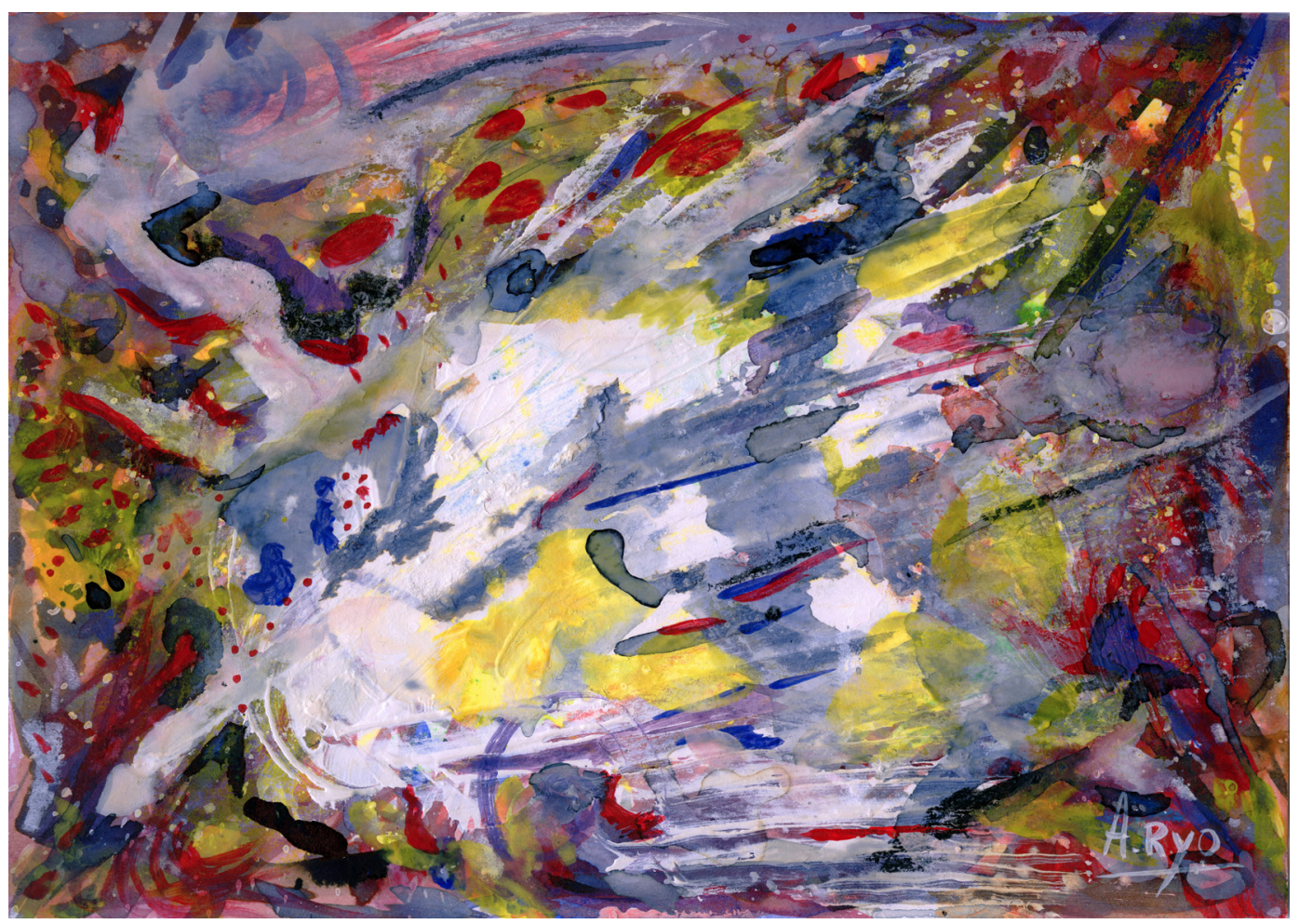

\title{
La amenaza estallando
}

\section{Técnica}

Técnica mixta sobre papel, $15 \times 21 \mathrm{~cm}$.

\section{Reflexión}

¿La amenaza? el otro, ¿la culpa? nuestra, no lo hacemos bien ¡no estés en familia, tampoco con amistades!. ¡Aléjate! peligro de muerte ¡No toques, abraces, ni beses! ¡desinfecta! ¡desinfecta!. No te acerques, distancia, culpabilizase, merecemos ser castigados, toque de queda, prohibido bailar. Ciencia ficción y realidad ficcionada, ahora confió, la vida siempre se abre paso, disfruto, bailo, vibro alto, mis defensas hermosas se alzan victoriosas.

\section{Autora}

Ana Rosa Arroyo

Licenciada en Bellas Artes por la Universidad del País Vasco.

Arteterapia: papeles de arteterapia y educación artística para la integración social. Monográfico: Las miradas del arte y el arteterapia en tiempos de la Covid19. ISSN-e: 1988-8309 https://dx.doi.org/10.5209/arte.75941 